\title{
Preliminary research on the relationship between site selection of Garden Expo and City-Take China (Jiangsu) international garden EXPO design as an example
}

\author{
Liu Wentao, ${ }^{1, a}$, Dai $\mathrm{Yu}^{2, \mathrm{~b}}$, Li Tian ${ }^{3, \mathrm{c}}, \mathrm{xiaoxuejian}^{4, \mathrm{~d} *}$ \\ 1,2,3,4 Jiang Xi Agricultural University, Qing Shan Lake District,Nanchang, Jiangxi Province ,China \\ awo5363032661@163.com, b360868753@qq.com, c1198200149@qq.com, \\ d*1198200149@qq.com
}

Keywords: location; relationship; Garden Expo; selection

\begin{abstract}
The Garden-show originated in western countries, aims to promote the development of garden and horticulture through exhibitions. In recent years, a variety of garden shows have been held in big cities, not only to promote the development of garden and horticulture, but also to provide a new opportunity for the development of the city. Garden Exposition is a major form of garden show, due to timeliness restrictions, targets are to achieve successfully in a period of time, and pay no attentions to the follow-up development, led to a large number of resources waste. At the same time, the number of visitors is plummeted, the garden maintenance costs a lot, most of the exhibitions are deserted. Facing these problems, sustainable development has become a trend and an important factor for evaluating the Garden Expo successful or not. After-use has close connections with the location of the garden. This paper analysis the locations of all the previous garden expositions in Jiangsu Province (China), looking for the relationships between the location and after-use, then, put forward some suggestions for the future garden exposition' s location[1].
\end{abstract}

\section{Introduction}

In 1993, China joined the International Exhibitions Bureau, marking a new era for China's Expo. Since the 21 st century, with the Improving constantly of Chinese political and economic status, various expositions have been held in China. The Garden Exhibition is one of them.

Garden Expo from the macro can be divided into: World-class Horticultural Exposition, National Horticultural Exposition, local-level horticultural exposition. local-level horticultural exposition, which is hosted by the local people's government of (province, city) or the national trade association, commercial company or the local people's government at the next lower level. The selection of site is usually at the city of own province, such as Jiangsu Horticultural Exposition and so on.

This article mainly takes the local horticultural exposition as the research object, and analyses the relationship between the Garden Expo and the city in Jiangsu province[2].

\section{Overview of Jiangsu Province Garden Expo}

In 1999, Kunming successfully held the World Horticultural Exposition in Kunming, Yunnan Province, and it has made a significant meaning and influence, which became an opportunity to promote the development of urban ecological construction in Jiangsu Province. In 1999, authorities proposed to hold the "Jiangsu Provincial Garden Expo", through the park Expo platform, we can enhance communication and cooperation in gardening, flowers and other industries, exhibit new achievements and new technologies, continuously improve the level of horticulture and gardening in Jiangsu Province, and accelerate the speed of urbanization.

Previous Garden exposition in Jiangsu province: 


\section{Analysis on the Relationship between the Site Selection of Garden Expo and the Original Urban Form in Jiangsu Province}

Considering the places of the Garden Expo, to show the regional characteristics, for optimizing and upgrading all kinds of resources around the area, and the using for when the venue ended. we should take more focus on the strategy of the development of the city. So, the selection of garden site should closely link with the original form of the city. The original form of the site in the city has positive effect on the theme, urban features, planning and design. In this chapter, we will analyze the context of the garden in Jiangsu Province and the primitive form in the city.

\subsection{Urban green space, parks and the former exhibition site or the old venue expansion}

Early, due to the primary study of the Garden Expo, the main consideration is the environmental factors. Relying on the green space, parks or previous exhibition sites, the expansion of the old venue is the main method in the early Garden Expo. This approach not only easily combines with urban features, making it easy to achieve beautiful environment and image with regional characteristic, reducing investments, obtaining more benefits about economy, culture and other aspects, but also reflects the strategy of sustainable development.

\subsection{Special geological, geographical form of the venue}

As a display platform of gardening and horticulture, Garden Expo usually selects the zone with superior landscape conditions as its exhibition area. According to different themes, basing the practical situation of the city, matching with geological environment, to enhance the urban features, for promoting the image of the city. Closing to the mountains and rivers is the primary feature of site selection of the Garden Expo.

\subsection{Urban Renewal}

With consecutive holding of Garden Expo and comprehensive research on the Garden Expo increasingly, the transformation of old city has become one of the most important model of site selection for Garden Expo. It is conducive to improve the municipal administration, transportation and environment in the region, boost the regional economy, abound the diversity of traditional culture. At the same time, it will cause the series of problems about demolition、 resettlement、 protection of historic sites and recycling of the venue, which indirectly increase the pre-investment and add more difficulties of planning and design .

\subsection{Combining the new district construction}

With accelerating of urbanization, the city has become very crowded. Cities need to be expanded to build new land, so a new model for the site selection of Garden Expo emerged - combining the new district construction. This model is similar to the transformation of the old city with large pre-investment which is also difficult to plan and design. However, the entire planning and design combining with Metro planning, basing on the construction of the new district, with a complete project of urban development, which is conducive to recycle of the venue.[3]

\section{The analyze basing on the relationship between the site of Garden Expo and city in Jiangsu Province}

\subsection{At the city center}

Early, Garden Expo as a major city events, the choice of site generally close to city center, relying on urban green space. But as a link between events and cities, it has limitation and plays a minor role in planning and re-development of cities. It only has a positive impact on municipal administration and urban ecology.

\subsection{Located on the edge of the city}

With researches deeply on the Garden Expo, the site of Garden Expo relocated from the city center to the edge of the city, and covering more and more space in the city. The large-scale construction of the Garden Expo has become a catalyst for urbanization. The connection between Garden Expo project and urban planning reflected on the site choose of Garden Expo on the area of old city renovation or new district of the city.

The site of Garden Expo located on the reconstruction area of old city, the large-scale 
construction of the Garden Expo aroused public attentions, which improved the quality of infrastructure and promoted the economy of surrounding area. Furthermore, it can promote the development of the city and make great contributions to the area of regeneration and provide a fresh environment for local people.[4]

The construction of new district is current mode for urban expansion, which also provide a new ideal for site selection of Garden Expo. The planning of Garden Expo accord with the general strategy of new districts planning[5].

\section{Garden Expo according with the city's development strategy}

5.1 Garden Expo as a major urban event of urban development

\begin{tabular}{|c|c|c|}
\hline Mode & \multicolumn{2}{|c|}{ As an influential event for urban development } \\
\hline $\begin{array}{l}\text { The original form of } \\
\text { the city }\end{array}$ & Urban green space, park & $\begin{array}{l}\text { Renovation and extension of } \\
\text { previous venue }\end{array}$ \\
\hline Location of Urban & City center & Centre or edge of city \\
\hline $\begin{array}{c}\text { strategy, } \\
\text { characteristics }\end{array}$ & $\begin{array}{c}\text { Renovation of historic } \\
\text { garden }+ \text { Optimizing construction of } \\
\text { urban landscape }\end{array}$ & $\begin{array}{l}\text { Space optimization and } \\
\text { upgrades + Extend and } \\
\text { renovation }\end{array}$ \\
\hline Planning Ideas & $\begin{array}{l}\text { Combining with the particularity of the } \\
\text { original landscape form; } \\
\text { Combining with the landscape with } \\
\text { special meaning; } \\
\text { Update facilities and landscape }\end{array}$ & $\begin{array}{c}\text { combined with regional } \\
\text { development; } \\
\text { Combined with planning of urban } \\
\text { open space; } \\
\text { Combined with the development of } \\
\text { surrounding plots }\end{array}$ \\
\hline Subsequent use & $\begin{array}{c}\text { Popular scenic spots + partially } \\
\text { exploited }\end{array}$ & $\begin{array}{c}\text { Urban green space }+ \text { partially } \\
\text { exploited }\end{array}$ \\
\hline Case & $\begin{array}{l}\text { Nanjing Park Expo } \\
\text { Changzhou Park Expo } \\
\text { Nantong Park Expo }\end{array}$ & $\begin{array}{l}\text { Xuzhou Park Expo } \\
\text { Huaian Park Expo }\end{array}$ \\
\hline General Features & $\begin{array}{l}\text { 1.Maintenance and renewal of historic } \\
\text { landscape spots } \\
\text { 2. The special information of the venue } \\
\text { is beneficial to the narration of the } \\
\text { theme of Park Expo } \\
\text { 3.Conbining with the traditional form } \\
+ \text { partly combined with urban } \\
\text { development with the Times }\end{array}$ & $\begin{array}{l}\text { 1.Optimizing the original space to } \\
\text { satisfy citizens and promoting the } \\
\text { regional environment } \\
\text { 2.Providing public green space for } \\
\text { citizens + Partial Reuse }\end{array}$ \\
\hline
\end{tabular}


5.2 Integrating into urban planning and serving urban development

\begin{tabular}{|c|c|c|}
\hline Mode & \multicolumn{2}{|c|}{ Integrate into urban planning and serve urban development } \\
\hline $\begin{array}{l}\text { The original form } \\
\text { of the city }\end{array}$ & Land of old town & Land of new zone \\
\hline Urban location & Urban edge & Urban new district \\
\hline $\begin{array}{l}\text { Vision, } \\
\text { characteristics }\end{array}$ & $\begin{array}{l}\text { Old city transformation and revival } \\
\text { Garden Expo + remodeling of old city }\end{array}$ & $\begin{array}{l}\text { Promote the development of new } \\
\text { zone } \\
\text { Improve green space system } \\
\text { Garden Expo + Green space } \\
\text { system }\end{array}$ \\
\hline Planning Ideas & $\begin{array}{l}\text { Combining the original spatial pattern } \\
\text { and characteristics } \\
\text { Consider the spatial relationship with } \\
\text { the surrounding environment } \\
\text { Driving the development of } \\
\text { surrounding districts }\end{array}$ & $\begin{array}{l}\text { Combined with the planning of } \\
\text { new zone } \\
\text { Combined with the development } \\
\text { strategy of new zone } \\
\text { Establishing links with certain } \\
\text { natural elements of the city }\end{array}$ \\
\hline Subsequent use & \multicolumn{2}{|c|}{ Independent integrated area + redevelopment of parts on the site } \\
\hline Case & Taizhou Garden Expo & $\begin{array}{c}\text { Suqian Garden Expo } \\
\text { Yangzhong Garden Expo }\end{array}$ \\
\hline General Features & $\begin{array}{l}\text { 1.The original traffic system and } \\
\text { infrastructure have constructed a } \\
\text { practical foundation for Garden Expo. } \\
\text { 2. The architectural style of the old City } \\
\text { reflected the theme of Garden Expo } \\
\text { 3.Promoting the construction of } \\
\text { regional ecology, economy and } \\
\text { urbanization } \\
\text { 4. As urban green space serving the } \\
\text { residents[6] }\end{array}$ & $\begin{array}{l}\text { 1.The new districts with wide base } \\
\text { are easy to construct the Garden } \\
\text { Expo. } \\
\text { 2. The theme coincides with the } \\
\text { strategy of new district } \\
\text { development } \\
\text { 3. The construction of the new } \\
\text { urban landscape is of great } \\
\text { significance to the regional } \\
\text { ecology, economy and } \\
\text { urbanization. } \\
\text { 4.As a leisure space for locals }\end{array}$ \\
\hline
\end{tabular}

\section{Conclusion}

Basing on the discussion of relationship between site selection of Garden Expo and urban development, starting from the original shape to the location of the city, the article takes the eight times of Garden Expo that is held in Jiangsu Province as an example. Discussing about the method of site choose for Garden Expo and using pattern of the park after exhibition. Summed up its original form, including urban green space, parks, the sites of former exhibition or the expansion of previous sites, I have discovered the transformation of geopolitical sites of Garden Expo from the urban park, public green space to previous urban sites or the undeveloped areas. As far as the site of Garden Expo, which moves from the city center to the outskirts of cities or the new urban area; The later using method of the site of Garden Expo is from single urban garden to integrated function area.

\section{References}

[1]. Shan Chen, G.N., Segmenting Chinese tourists by the expected experience at theme parks. Social and Behavioral Sciences, 2014. 109: p. 1230 - 1236.

[2]. Xiao, W. and Z. Si, Green darning city, taking the tenth China (Wuhan) international garden EXPO design as examples. Engineering, 2017: p. 383 - 392. 
[3]. Zhang, L.Y.Y.J., Rotifer community structure and its response to environmental factors in the Backshore Wetland of Expo Garden, Shanghai. Aquaculture and Fisheries, 2017(1-8).

[4]. van den Brink, A.K.A.A., Regional designing: A strategic design approach in landscape architecture. Design Studies, 2018. 54.

[5]. Yiqun Fan, K.Y., Consideration about effects of the Expo Axis underground space on development of surrounding regions as "Urban Catalysis". Engineering, 2016. 29-39(165).

[6]. Wangzhinan, G.J.C., From the Garden Expo to study planning and design of garden presentation. Chinese Garden, 2008(1000-6664(2010)01-0075-03). 